\title{
接触分析法を利用する天然水及び水道水中の 極微量銅のスペシェーション分析
}

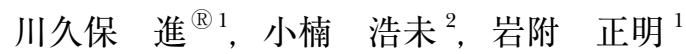

\begin{abstract}
接触分析法は高感度な金属イオンの定量法であるだけでなく, 触媒活性を示す反応性金属イオンの化学的 結合状態を特定できれば，存在状態についての情報を与えるスペシエーション法となりうるが，このような 観点からの応用研究は極めて少ない，本研究では，溶存酸素による $\mathrm{L}-$ アスコルビン酸の酸化反応における銅 の触媒作用を利用し，この反応によって生じるデヒドロアスコルビン酸をo-フェニレンジアミンと反応させ てキノキサリン化合物 $(\mathrm{QX})$ を生成させ $\left(\mathrm{pH} 6.9,25{ }^{\circ} \mathrm{C}\right)$, 反応 5 分後の吸光度を $340 \mathrm{~nm}$ で測定すること により，検出限界 $0.1 \mu \mathrm{g} \mathrm{L}^{-1}$ (酸性試料の場合, $0.5 \mu \mathrm{g} \mathrm{L}^{-1}$ ) で $0 \sim 7 \mu \mathrm{g} \mathrm{L}^{-1}$ の反応性銅が定量できる方法を 開発した．異なる銅シュウ酸錯体の反応性の違いを利用して $\mathrm{Cu}^{2+}$ または $\mathrm{Cu}^{\mathrm{II}} \mathrm{L}_{\mathrm{i}}$ (配位子 $\mathrm{L}$ が単座配位子の場 合は $i=1$ または 2 , 二座配位子の場合は $i=1 ）$ が反応性を示すことを明らかにした．本法を水道水と河川 水中の銅のスペシエーションに応用し, 本法の有用性を示した.
\end{abstract}

\section{1 緒言}

環境水に含まれる金属成分は，共存成分と結合して様々 な物理化学的状態をとりうるため, その状態によって移動 や分布が変わり，反応性（lability）の違いは生体への摂取 や毒性に影響する。，そのため，目的成分を反応性・非反応 性についての状態別定量（スペシエーション）が重要であ るが，操作条件によっては目的成分の存在状態が変わり， 正しく分析できない ${ }^{1}$. 例えば，イオン交換性の成分や有 機錯体を形成して溶媒抽出できる成分を反応性化学種とし て測定する場合，イオン交換分離ではキレート樹脂に保持 されないはずの非イオン性金属成分が保持されることがあ り, 溶媒抽出では加えたキレート試薬が, 本来錯体化して いた目的成分を分解する場合がある，ストリッピング・ボ ルタンメトリーは，感度がよいため反応性化学種を直接測 定できるが, 試料水と電極の間の不均一反応を利用するた めに反応が複雑で, 反応性化学種の状態を特定することが 困難であった。このほか, 天然水試料を酸性にすると, フ ミン物質と結合していた金属イオンは解離して反応性を示 すようになる2．著者らは，接触分析法（接触法）が, 反 応性金属イオン（触媒）に選択的な定量法として有用であ るとともに，触媒活性錯体の形態を明らかにすることに よって目的成分と共存成分との結合状態が分かり，優れた

\footnotetext{
${ }^{1}$ 山梨大学大学院医学工学総合研究部 : 400-8511 山梨県甲府市 武田 4-3-11

2 山梨大学工学部物質 - 生命工学科 (現応用化学科) : 400-8511 山梨県甲府市武田 4-3-11
}

スペシエーション法になりうること示した ${ }^{3) 4)}$. 接触法は, 均一反応であることから, ストリッピングボルタンメト リーに比べて触媒活性錯体の形態の解析が容易であるが, 鉄イオンについての解析と応用しかない( ${ }^{3)}$-5). 本研究で は, 0 -フェニレンジアミン（OPDA）共存下で溶存酸素に よる L-アスコルビン酸（AA）の酸化発色反応 ${ }^{6}$ を利用する 極微量反応性銅のスペシエーション法を開発し, 水道水と 河川水に応用してその有用性を示した.

$$
2 \text { 実験 }
$$

\section{$2 \cdot 1$ 試薬及び装置}

試薬は特記しない限り市販特級品を用い, 水はミリポア 製 Simpli-Lab-UVで精製したものを用いた，水酸化ナトリ ウム溶液, 塩酸, 硝酸の各溶液は関東化学製高純度試薬 Ultrapur $^{\circledR}$ を使った. 銅 (II) 標準溶液は, 硫酸銅 (II) 五水和 物を $1 \mathrm{mM}$ 塩酸で溶解したものを適宜 $1 \mathrm{mM}$ 塩酸で希釈し て調製した. AA 溶液は, L-アスコルビン酸試薬を $0.5 \mathrm{M}$ 塩 酸 $50 \mathrm{~mL}$ に溶解し, 6 時間以内に使用した. OPDA 溶液は, $o$-フェニレンジアミン試薬を水で溶解し, 冷蔵庫 $\left(5{ }^{\circ} \mathrm{C}\right)$ 内 に保存して 1 日以内に使用した.フルボ酸（FA）溶液は, 蛍光スペクトルが天然河川水に類似していたDando フル ボ酸 (愛知県段戸, 褐色森林土壤 $)^{5) 7}$ を水に溶かして調製 した (6.4 $\left.\mathrm{mg} \mathrm{FA} \mathrm{L}^{-1}\right)$.

吸光度は, 島津 UV-160A 分光光度計に角型石英ガラス製 セル（光路長 $1 \mathrm{~cm} ）$ を装着して測定した. 恒温水槽（25 $\left.\pm 0.1{ }^{\circ} \mathrm{C}\right)$ の水を, 分光光度計のセルホルダーに循環させ, 一定の反応温度で吸光度を測定した。試料水の沪過にはア 
ドバンテック東洋製 LABODISC ${ }^{\circledR}$ 膜フィルターユニット （孔径 $0.45 \mu \mathrm{m}$, 酢酸セルロース製フィルター）を用いた. 限外沪過には Pall 製 Microsep ${ }^{\circledR}$ 遠心式沪過器（分画分子量 $1000 \mathrm{Da}$ ）を用い, 沪過器に $0.05 \mathrm{M}$ アンモニア水, 水を順 次流して洗浄した後, 使用した.

\section{$2 \cdot 2$ 分析操作}

採取現場で水試料を沪過した後, 汇液を試料としてポリ スチレン製容器（容積 $120 \mathrm{~cm}^{3}$ ) に入れ, $5{ }^{\circ} \mathrm{C}$ の冷暗所に 保存した，分析する前に試料は室温に放置した。 また，試 薬溶液と水は恒温水槽で反応温度 $\left(25{ }^{\circ} \mathrm{C}\right)$ に保った. 反応 性銅を定量する場合, 試料を共栓付きガラス製試験管（容 積 $20 \mathrm{~mL}$ ) に採り, $25{ }^{\circ} \mathrm{C}$ で 3 分間放置して液温を反応温

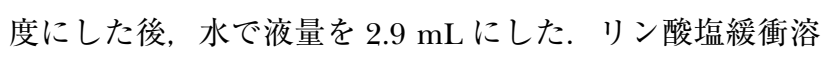
液 $\left(17.5 \mathrm{mM} \mathrm{Na}_{2} \mathrm{HPO}_{4}-17.5 \mathrm{mM} \mathrm{NaH} \mathrm{PO}_{4}-70.5 \mathrm{mM}\right.$ $\mathrm{NaOH}) 1.0 \mathrm{~mL}$ と $25 \mathrm{mM}$ OPDA 溶液 $1.0 \mathrm{~mL}$ を加えた後, $0.25 \mathrm{M} \mathrm{AA}$ 溶液 (0.5 M HCl) $0.10 \mathrm{~mL}$ を加えて反応を開始 させた. 反応時間 5 分における $340 \mathrm{~nm}$ の吸光度を, 水を 対照にして測定した，検量線は，試料の代わりに銅(II) 標 準溶液を加えて反応させて作成した．非反応性銅を定量す る場合, 試料に塩酸を加えて $0.1 \mathrm{M}$ 塩酸溶液にして 1 日放 置した。 その後, 溶液の一部を分取して共栓付きガラス製 試験管に採り，1 M 水酸化ナトリウム溶液を加えて中和 し, $25{ }^{\circ} \mathrm{C}$ で 3 分間放置した. 以下, 反応性銅の定量と同 様に水やリン酸塩緩衝溶液などを加えて反応させ, 吸光度 を測定した，検量線は，試料の場合と同量の塩酸と水酸化 ナトリムを加えた後, 反応させて作成した. 得られた定量 值を溶存態銅濃度（孔径 $0.45 \mu \mathrm{m}$ の膜フィルターを通過す る銅の総濃度）とし，この值から反応性銅濃度を引いて非 反応性濃度を求めた.

鉄(III) の妨害があるときは, 水で一定液量にする前に $0.28 \mathrm{mM}$ シュウ酸 $0.1 \mathrm{~mL}$ を加えた. 試験管とセルは, $1 \mathrm{M}$ の塩酸 (又は硝酸) と水で順次洗った後, 再使用した。

\section{3 結果及び考察}

\section{$3 \cdot 1$ 銅の定量}

中性溶液中で銅を触媒とする AA の酸化反応は次の反応 式で表すことができる ${ }^{8) 9}$.

$$
\begin{aligned}
& 2 \mathrm{Cu}^{2+}+\mathrm{HAA}^{-}+\mathrm{OH}^{-} \rightarrow 2 \mathrm{Cu}^{+}+\mathrm{DAA}+\mathrm{H}_{2} \mathrm{O} \\
& 2 \mathrm{Cu}^{+}+\mathrm{O}_{2} \rightarrow 2 \mathrm{Cu}^{2+}+\mathrm{O}_{2}{ }^{2-} \\
& \mathrm{O}_{2}{ }^{2-}+\mathrm{HAA}^{-}+\mathrm{H}^{+} \rightarrow \mathrm{DAA}+2 \mathrm{OH}^{-}
\end{aligned}
$$

ここで $\mathrm{HAA}^{-}$は $\mathrm{AA}$ にプロトン付加したものを示し, $\mathrm{O}_{2}$ は 溶存酸素である.これらの反応より $\mathrm{AA} の$ 酸化反応は

$$
2 \mathrm{HAA}^{-}+\mathrm{O}_{2} \rightarrow 2 \mathrm{DAA}+2 \mathrm{OH}^{-}
$$

で表せ，OPDAを共存させることによって

$$
2 \mathrm{DAA}+2 \mathrm{OPDA} \rightarrow 2 \mathrm{QX}+4 \mathrm{H}_{2} \mathrm{O}
$$

の反応により蛍光性の黄色キノキサリン化合物 QX \{3-(1,2-dihydroxyethyl)furo [3,4-b] quinoxalin-1-one $\}$ が生 成する. 反応速度式は反応式 $(4)$ ，（5）の逐次反応によっ て表せ, 反応初期において $\mathrm{QX}$ の蛍光強度が反応時間 $t$ の 二乗に比例し, その比例係数と触媒濃度 $[\mathrm{Cu}]$ の関係を検 量線にして銅が定量できることを著者らは示した ${ }^{6)}$ 。この 場合, QX の生成量の少ない反応初期でも感度よく QX 測定するために蛍光測定を用いたが, AA 溶液を保存する 際にも反応式 (4) によってDAA が生成し, それが定量を 妨害するため, $\mathrm{AA}$ 溶液を $5{ }^{\circ} \mathrm{C}$ に冷却して保存する必要が あった。一方，モリブデンを触媒とする過酸化水素による AA の酸化反応に関する研究で, 著者らは, 反応速度への 反応試薬濃度の影響が無視できる反応範囲において, 反応 初期を過ぎたところで $[\mathrm{QX}]$ が $[\mathrm{Cu}]$ に比例することを導 き出した ${ }^{10)}$. この誘導を反応式 $(4),(5)$ に適用すると, 反応式 $(4),(5)$ の速度式はそれぞれ $-\mathrm{d}\left[\mathrm{HAA}^{-}\right] / \mathrm{d} t=$ $k_{1}[\mathrm{Cu}]+k_{2}, \mathrm{~d}[\mathrm{QX}] / \mathrm{d} t=k_{3}[\mathrm{DAA}]$ で表せ,

$$
[\mathrm{QX}]=\left(k_{1}[\mathrm{Cu}]+k_{2}\right) t-\left(k_{1}[\mathrm{Cu}]+k_{2}\right) / k_{3}+[\mathrm{DAA}]_{0}
$$

が導かれる.ここで $k_{1} \sim k_{3}$ は定数, $[\mathrm{DAA}]_{0}$ は $\mathrm{AA}$ 溶液か ら混入した DAAの濃度である. 式 $(6)$ は一定反応時間 $\left(\left(t=t_{\tau}\right)\right.$ のとき

$$
[\mathrm{QX}]=k_{4}[\mathrm{Cu}]+k_{5}
$$

となる.ここで $k_{4}$ と $k_{5}$ はそれぞれ $k_{4}=k_{1}\left(t_{\tau}-1 / k_{3}\right), k_{5}=$ $k_{2}\left(t_{\tau}-1 / k_{3}\right)+[\mathrm{DAA}]_{0}$ の定数であり, 式 $(7)$ を使って銅が 定量できる.この反応範囲では反応初期に比べて発色が進 むので， $[\mathrm{QX}]$ に対する $[\mathrm{DAA}]_{0}$ の影響が相対的に小さな る $^{10)}{ }^{11)}$.このため, 本法では $\mathrm{AA}$ 溶液は $25{ }^{\circ} \mathrm{C}$ でも少なくと も6時間使用できるようになった. また, 発色が進むと QX 自身による蛍光の吸収が起こるので QX の吸光度を測定し た. さらに, 蛍光測定の場合 ${ }^{6}$ に比べて OPDA の濃度を 10 倍濃くすることによって反応を速くし, 吸光度測定でも迅 速に測定できるようにした。このほか, リン酸塩の濃度を 銅の反応性に影響のない程度まで低くした（蛍光測定の 1/7). $2 \cdot 2$ の反応性銅の定量操作に従って反応させたとき の吸収スペクトルは $340 \mathrm{~nm}$ で極大を示したので〔Fig. 1 (A) ]，この波長を $\mathrm{QX}$ の測定波長とした．異なる銅濃度に おける反応曲線を Fig. 1（B）に示す. 反応時間 4 min から $10 \min$ の間の一定反応時間における吸光度は銅濃度に比 

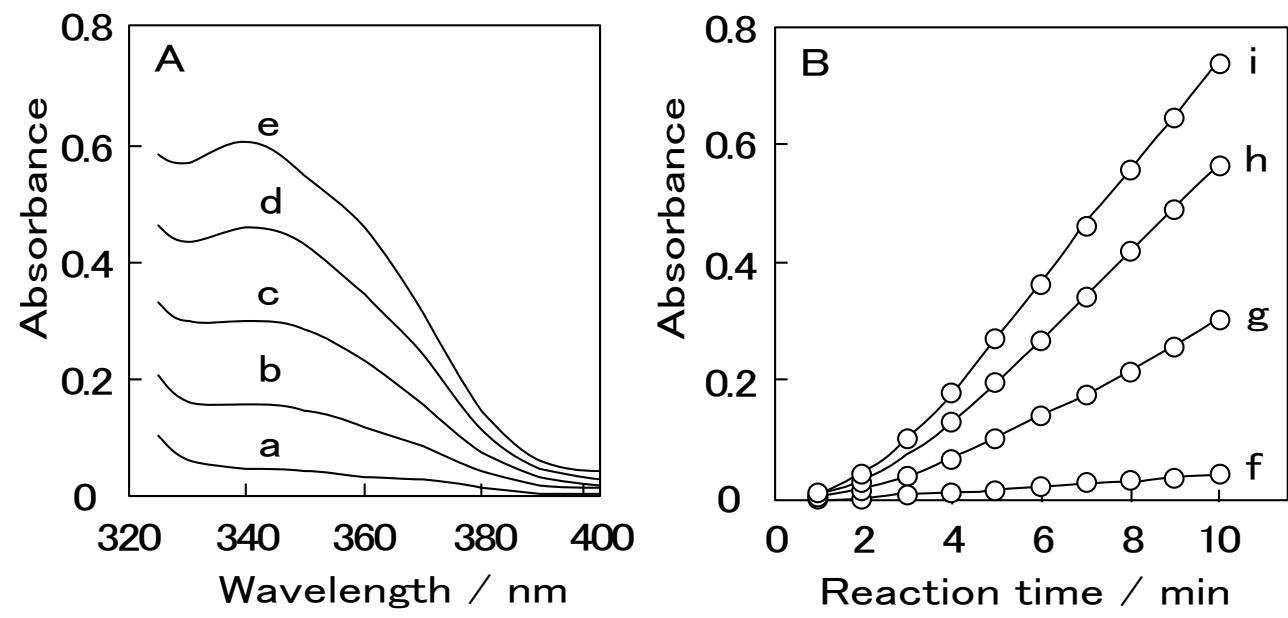

Fig. 1 Absorption spectra (A) for $4 \mu \mathrm{g} \mathrm{L}^{-1}$ of $\mathrm{Cu}$ (II) at reaction time of 2 (a), 4 (b), 6 (c), 8 (d) and 10 (e) $\mathrm{min}$ and reaction curves (B) for reagent blank (f), 2 (g), $4(\mathrm{~h})$, and 6 (i) $\mu \mathrm{g} \mathrm{\textrm {L } ^ { - 1 }}$ of $\mathrm{Cu}(\mathrm{II})$ under the conditions of $5 \mathrm{mM}$ $\mathrm{AA}, 5 \mathrm{mM}$ OPDA at $\mathrm{pH} 6.9$ and $25{ }^{\circ} \mathrm{C}$.

例し，その関係の相関係数は 0.999 以上であった．本法で は分析の迅速性を考慮して $5 \mathrm{~min}$ の吸光度を測定して銅を 定量することにした．銅の検量線は $7 \mu \mathrm{g} \mathrm{L}^{-1}$ の銅濃度（吸 光度 0.35 ) まで相関係数 0.999 で直線性を示した. $4 \mu \mathrm{g} \mathrm{L}^{-1}$ の銅を 5 回定量したときの定量値の相対標準偏差は $3 \%$ で あった. 試薬ブランクの吸光度を 5 回繰り返し測定して得 た標準偏差の 3 倍に相当する銅濃度を検出限界とすると き，その值は $0.1 \mu \mathrm{g} \mathrm{L}^{-1}$ で蛍光測定と大差なかった．塩化 ナトリウムの共存はイオン強度に影響するが，その影響と 思われる銅の触媒効果の低下が認められた，そこで，塩酸 酸性試料の分析では, 試料の場合と同じ濃度になるように 塩酸と水酸化ナトリウム溶液を加えて検量線を作成した。 $0.1 \mathrm{M}$ 塩酸酸性試料 $2 \mathrm{~mL}$ を分析するとき, 銅の検出限界 は $0.5 \mu \mathrm{g} \mathrm{L}^{-1}$ であった。本法では, 試料中の固体粒子（粒 径 $0.45 \mu \mathrm{m}$ 以下）を塩酸酸性にして溶かし，銅を解離させ て反応性銅として溶存態銅を定量する．2.2 の分析操作で は，溶液は再び中性になるが, 河川水や水道水の場合, 10 分程度ならば, 溶けた物質〔コロイド状水酸化鉄(III) や鉄 フミン酸凝集体〕が中和によって析出することはない ${ }^{3)}$ の で，溶けた銅をそのまますべて定量できる．

蛍光測定で銅の定量に影響があった化学種を中心に天然 淡水に含まれる代表的な成分の影響を調べた，定量誤差 $5 \%$ となる最大濃度（反応溶液中の濃度）を許容量として 求めた結果を Table 1 に示す. $\mathrm{Hg}(\mathrm{II}), \mathrm{Sn}(\mathrm{IV}), \mathrm{V}(\mathrm{V})$, $\operatorname{Cr}(\mathrm{VI})$ は, 比較的影響が大きいが, 河川水や湖水などの天 然淡水に含まれる濃度 ${ }^{12}$ は許容量に比べて低いので, 多く の試料でこれらの影響は無視できる. Fe(III) は正の定量誤 差を与え, 共存するリン酸塩濃度を蛍光法より低くしたた め, 蛍光測定に比べてリン酸イオンによるマスキング効果 が小さくなり, $\mathrm{Fe}(\mathrm{III})$ の許容量は $1 / 10$ になった. 蛍光測 定では亜硝酸塩の添加により $\mathrm{Fe}(\mathrm{III})$ の妨害を十分抑える
Table 1 Effects of foreign species on the determination of $4 \mu \mathrm{g} \mathrm{L}^{-1}$ of copper

\begin{tabular}{llc}
\hline Interference & \multicolumn{1}{c}{ Species } & $\begin{array}{c}\text { Tolerance Limit/ } \\
\mathrm{mg} \mathrm{L}^{-1}\end{array}$ \\
\hline None $^{\mathrm{a})}$ & $\mathrm{Cl}^{-}$ & 15 \\
& $\mathrm{Na}(\mathrm{I})$ & 10 \\
& $\mathrm{Tartrate}$ ion & 0.5 \\
Positive & $\mathrm{PO}_{4}{ }^{3-}$ & 700 \\
& $\mathrm{~F}^{-}$ & 500 \\
& $\mathrm{Fe}(\mathrm{III})$ & $0.02^{\mathrm{b})}$ \\
& $\mathrm{Fe}(\mathrm{III}), \mathrm{V}(\mathrm{V})$ & 0.005 \\
Negative & $\mathrm{Si}(\mathrm{IV})$ & 10 \\
& $\mathrm{C}_{2} \mathrm{O}_{4}{ }^{2-}$, citrate ion & 0.5 \\
& $\mathrm{Humic}$ acid, fulvic acid & 0.2 \\
& $\mathrm{Hg}(\mathrm{II})$ & 0.04 \\
& $\mathrm{Sn}(\mathrm{IV}), \mathrm{Cr}(\mathrm{VI})$ & 0.01 \\
\hline
\end{tabular}

a) Maximum concentration tested. b) In the presence of $5.6 \mu \mathrm{M} \mathrm{C}_{2} \mathrm{O}_{4}{ }^{2-}$.

ことができたが6)，本法では不十分であった，亜硝酸イオ ンは, $\mathrm{Fe}(\mathrm{III})$ AA で還元して 1,10-フェナントロリンで発 色させる反応を遅くした．この結果は, 蛍光測定に比べて 反応時間が経過したところを測定する本法では, $\mathrm{Fe}(\mathrm{III})$ の 還元を抑えにくく，亜硝酸塩の効果が小さくなることを示 唆する. 本法では, 定量值に影響しない程度のシュウ酸ナ トリウムを加えることにし，これによって許容量を 20 $\mu \mathrm{g} \mathrm{L}^{-1}$ まで上げることができた。 これより，試料量 $1 \mathrm{~mL}$ を分析する場合の試料中の許容濃度は $100 \mu \mathrm{g} \mathrm{L}^{-1}$ となり, 河川水に含まれる鉄の推定平均濃度 $\left(40 \mu \mathrm{g} \mathrm{L}^{-1}\right)^{12}$ は十分 許容できる，さらに，溶存態鉄で反応性を示すものは河川 水で $20 \sim 50 \%{ }^{5)}$, 水道水で $10 \%$ 以下 ${ }^{3)}$ であることを考虑 すれば，試料量を多くして感度よく分析することも可能と 言える. 銅イオンと錯体を形成する EDTA は $10 \mu \mathrm{g} \mathrm{L}^{-1}$ の 


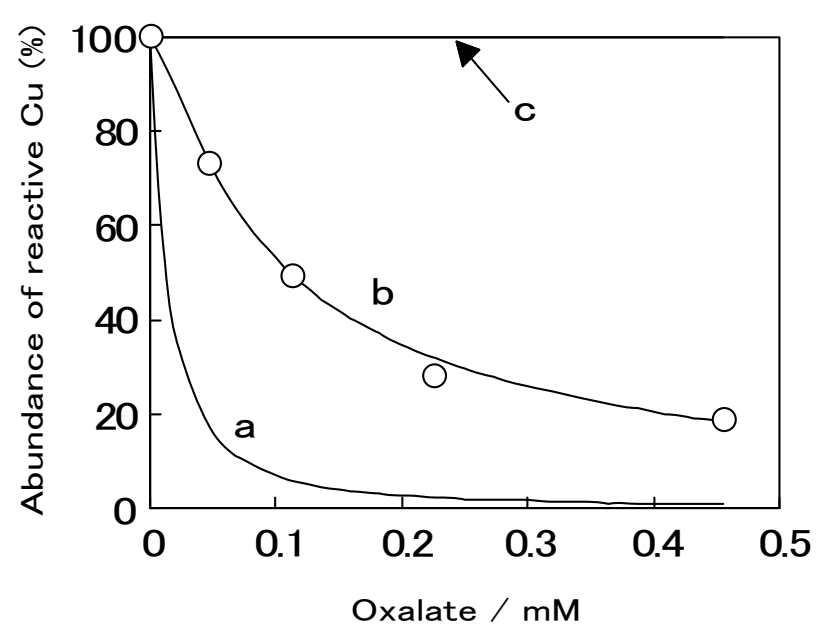

Fig. 2 Abundances of reactive copper $(\bigcirc)$ in the presence of $4 \mu \mathrm{g} \mathrm{L}^{-1}$ of $\mathrm{Cu}(\mathrm{II})$ and different concentrations of oxalate. Lines indicate calculated abundances of $\mathrm{Cu}^{2+}$ (a), $\mathrm{Cu}^{2+}+\mathrm{CuOx}$ (b) and $\mathrm{Cu}^{2+}+$ $\mathrm{CuOx}+\mathrm{Cu}(\mathrm{Ox})_{2}{ }^{2-}$ (c).

共存で $10 \%$ の負の誤差を与えた. フミン酸とフルボ酸は 負の定量誤差を示すが, これらは金属イオンと錯体形成す ることが知られているので，その影響は銅のスペシエー ションのおいては重要な情報となる.

\section{$3 \cdot 2$ 反応性銅の存在状態の推定}

銅 (II) とシュウ酸イオンの錯体の割合と反応性を示す銅 の割合を比較して反応性銅の化学形態を推定した. pH 6.9 で錯体を形成させるため, 緩衝溶液を加えて $\mathrm{pH} 6.9$ にす る直前に銅 $(\mathrm{II})$ 標準溶液 (pH 3) とシュウ酸ナトリウム溶 液を混合した. シュウ酸 $\left(\mathrm{H}_{2} \mathrm{Ox}\right)$ の生成定数 ${ }^{13)}$ からシュウ 酸イオンは pH 6.9 においてはプロトンが付加していない 状態 $\left(\mathrm{Ox}^{2-}\right)$ で存在する. $\mathrm{Cu}(\mathrm{II})$ イオンと各種の銅シュウ 酸錯体の存在割合はイオン強度 $0.1,25{ }^{\circ} \mathrm{C}$ の錯体の生成定 数 ${ }^{13)}\left\{[\mathrm{CuOx}] /\left(\left[\mathrm{Cu}^{2+}\right]\left[\mathrm{Ox}^{2-}\right]\right)=10^{4.85},\left[\mathrm{Cu}(\mathrm{Ox})_{2}{ }^{2-}\right] /\right.$ $\left.\left([\mathrm{CuOx}]\left[\mathrm{Ox}^{2-}\right]\right)=10^{4.01}\right\}$ から求めた. 反応性銅の存在割 合と $\mathrm{Cu}(\mathrm{II})$ イオンと各種の銅シュウ酸錯体の存在割合 (計算值) を比較した結果を Fig. 2 に示す. 反応性銅の存在 割合は $\left[\mathrm{Cu}^{2+}\right]+[\mathrm{CuOx}]$ の割合に一致した.このことは, $\mathrm{Cu}^{2+}$ と $\mathrm{CuOx}$ の銅が直接定量できる反応性銅であり, $\mathrm{Cu}(\mathrm{Ox})_{2}{ }^{-}$は定量できない非反応性銅であることを示す. 従って, 反応性銅は $\mathrm{Cu}^{2+}$ と銅 (II) 錯体 $\mathrm{Cu}^{\mathrm{II}} \mathrm{L}_{\mathrm{i}}$ （L が単座配 位子のとき $i=1$ 又は 2 , 二座配位子のとき $i=1$ ) である ことが明らかになった. 銅 $(\mathrm{I})$ は溶存酸素によって酸化さ れやすいので天然淡水中の銅イオンは銅(II) として扱え る. 銅 (II) による AA の酸化において $\mathrm{Cu}^{\mathrm{II}}(\mathrm{HAA})^{+}$の活性錯 体が形成すると考えられるので ${ }^{814)}$ ，この形成を妨げない 形態, すなわち銅 (II) イオンの四つの配位位置が最大二つ まで配位子と結合している化学種が反応性銅として定量で
きことを示唆し, Fig. 2 の結果と一致する.

\section{$3 \cdot 3$ 実際試料への応用}

山梨大学構内の水道水と甲府市市内を流れる河川水を採 取し, 孔径 $0.45 \mu \mathrm{m}$ のフィルターで沪過した沪液を試料と した．鉄をマスキングするために $5.6 \mu \mathrm{M}$ のシュウ酸ナト リウムを加えた. 水道水や河川水では, 溶存態固体粒子 $(<0.45 \mu \mathrm{m})$ 中の代表的金属元素である鉄が, 試料を $0.1 \mathrm{M}$ 塩酸酸性にすることによってイオン化でき ${ }^{3)}$, 河川水 に含まれる溶存態の銅はキレート型樹脂で分離できる形態 (イオン) であるとの報告 ${ }^{15}$ )があるので, 本法では塩酸酸性 で溶出して反応性を示す銅を溶存態銅濃度の全量とした. $2 \cdot 2$ に従って分析した結果を Table 2 に示す. 水道水 (試料 A）では, 原子吸光分析法による值と誤差内で一致した. 河 川水に含まれる銅は, 本法では測定できたが, 原子吸光分 析法では検出できない濃度 $\left(<3 \mu \mathrm{g} \mathrm{L}^{-1}\right)$ であった. 20 $\mu \mathrm{g} \mathrm{L}^{-1}$ の銅 (II) を添加して放置した荒川河川水を本法と原 子吸光分析法で分析した值は $10 \%$ 以内の誤差で一致し た. 試料 A， B， D， F に $10 \mathrm{ng}$ の銅(II）を加えて本法で添 加回収実験した結果, 誤差 $6 \%$ 以内で銅が回収できた.

試料 $\mathrm{A}$ の水道水 $(\mathrm{pH}$ 7) は数か月使用しなかった蛇口か ら採取したが，他の試料に比べて溶存態銅濃度が最も高 く，配管からの銅の溶出が考えられた．水道水については 非反応性銅の割合が 40 ～65\% であったが, pH 7 におけ る銅 (II) の加水分解生成物は, 化学平衡 ${ }^{13)}$ から $76 \%$ は $\mathrm{Cu}^{2+}, 24 \%$ は $\mathrm{CuOH}^{+}$として存在することになり, 非反応 性銅の存在を示すことはできなかった。一方，水道水はコ ロイド状水酸化鉄 (III) を含むので ${ }^{3)}, 5 \mu \mathrm{g} \mathrm{L}^{-1}$ の銅(II) と $30 \mu \mathrm{g} \mathrm{L}^{-1}$ の鉄 $(\mathrm{III})$ を含む擬似水道水を調製し, その沪液 を分析した．擬似水道水中の銅は約 $30 \%$ が非反応性であ り, 実際試料に近い状態が再現できた。このような非反応 性銅は水酸化鉄(III) のコロイド粒子中に取り达まれた銅 であると考えられる.

河川水試料では溶存態銅の大部分が非反応性銅であっ た. 非反応性銅は, コロイド状水酸化鉄 (III) や鉄 (III) フ ミン酸凝集体に取り込まれた銅と考えられる ${ }^{5) 16)}$. 反応性 銅は溶存態銅の 10 又は $20 \%$ で, 異なる河川水系における 反応性銅 (ジチゾン抽出性銅 $)^{17)}$ と同程度の割合であった. 森林土壌の水抽出液を Amicon ${ }^{\circledR}$ 遠心式沪過器 (分画分子量 $1000 \mathrm{Da})$ で限外沪過すると, イオン性銅は限外沪過フィ ルターに吸着し，有機性銅錯体は吸着されないことが報告 されている ${ }^{18)}$. この性質を利用して河川水中の銅の存在状 態を推定した. Microsep ${ }^{\circledR}$ 遠心式沪過器でも, 銅 (II) 溶液 $\left(10 \mu \mathrm{g} \mathrm{L}^{-1}, \mathrm{pH} 7\right)$ では 3 又は $4 \%$ の銅しか沪過器を通過 せず，イオン性銅 $\left(\mathrm{Cu}^{2+}+\mathrm{CuOH}^{+}\right)$の著しい沪過損失が 認められた. 他方, 比較的低分子量のフミン物質である $\mathrm{FA}$ を含む擬似河川水として $2 \mu \mathrm{g} \mathrm{L}^{-1}$ の銅 (II) と $500 \mu \mathrm{g} \mathrm{L}^{-1}$ の 
Table 2 Speciation results of copper in tap and river water samples ${ }^{\text {a) }}$

\begin{tabular}{|c|c|c|c|c|}
\hline & Sample & Dissolved $\mathrm{Cu}^{\mathrm{b})} / \mu \mathrm{g} \mathrm{L}^{-1}$ & Reactive $\mathrm{Cu} / \mu \mathrm{g} \mathrm{L}^{-1}$ & Unreactive $\mathrm{Cu} / \mu \mathrm{g} \mathrm{L}^{-1}$ \\
\hline A & Tap water & $\begin{array}{l}43 \pm 2(n=5) \\
40 \pm 1^{c)}(n=3)\end{array}$ & $28 \pm 2(n=4)$ & 15 \\
\hline B & Tap water & $3.5 \pm 0.3(n=3)$ & $1.7 \pm 0.1(n=3)$ & 1.8 \\
\hline C & Tap water & $2.3 \pm 0.3(n=4)$ & $1.0 \pm 0.1(n=4)$ & 1.3 \\
\hline $\mathrm{D}$ & Nigorigawa river water & $\begin{array}{c}2.9 \pm 0.2(n=3) \\
<3^{\mathrm{c})}\end{array}$ & $0.3 \pm 0.1(n=3)$ & 2.6 \\
\hline $\mathrm{E}$ & Arakawa river water & $\begin{array}{c}2.3 \pm \\
<.3(n=4) \\
<3^{\mathrm{c})}\end{array}$ & $0.5 \pm 0.1(n=3)$ & 1.8 \\
\hline $\mathrm{F}$ & Arakawa river water & 1.7, 2.0 (Av.1.9) & $0.2 \pm 0.1(n=5)$ & 1.7 \\
\hline
\end{tabular}

a) Samples were filtered through a membrane filter with a pore size of $0.45 \mu \mathrm{m}$ and a $0.5-2 \mathrm{~mL}$ aliquot was taken for analysis. b) Determination results for acidified samples. c) Determination results by flame atomic absorption spectrometry.

FA を含む溶液 $(\mathrm{pH} 7)$ を調製して分析した結果, 銅の $100 \%$ （FA では $80 \%$ ）が限外沪過フィルターを通過した. 荒川河川水（試料 F）では反応性銅のほぼ全量が限外沪過 フィルターを通過したので, フミン酸やフルボ酸と錯体を 形成している銅と考えられる ${ }^{17) 19) 20)}$. 濁川と荒川の河川水 試料はフミン物質の約 $80 \%$ が $1000 \mathrm{Da}$ 以下のフルボ酸で あったので ${ }^{5)}$, 荒川河川水の反応性銅はフルボ酸錯体を形 成していると思われる. 銅フルボ酸錯体は銅イオンに比べ て細菌に対する毒性が低いとの報告があり ${ }^{21)}$, このような 成分が測定できる本法は淡水試料の水質や毒性の研究に有 用である.

\section{謝辞}

本研究の一部は文部科学省科学研究費補助金（研究課題 番号 15550066）による. 記して謝意を表する.

\section{文献}

1) T. M. Florence, G. E. Batley : CRC Crit. Rev. Anal. Chem., 9, 220 (1980) ; W. F. Pickering: "Chemical Speciation in the Environment", Edited by A. M. Ure, C. M. Davidson, 2nd Ed., p. 22 (2001), (WileyBlackwell, Oxford UK).

2) S. Kawakubo, M. Iwatsuki : Anal. Sci., 16, 945 (2000).

3) S. Kawakubo, Y. Hagihara, Y. Honda, M. Iwatsuki : Anal. Chim. Acta, 388, 35 (1999).

4) S. Kawakubo, Y. Okazaki, M. Iwatsuki : Anal. Sci., 19, 373 (2003).

5) S. Kawakubo, K. Tachikawa, M. Iwatsuki : J. Environ.
Monit., 4, 263 (2002).

6) S. Kawakubo, H. Kato, M. Iwatsuki : Analyst (London), 119, 2119 (1994).

7) A. Watanabe, K. Itoh, S. Arai, S. Kuwatsuka : Soil Sci. Plant Nutr., 40, 601 (1994).

8) K. Hayakawa, S. Minami, S. Nakamura : Bull. Chem. Soc.Jpn., 46, 2788 (1973).

9) N. Navon, H. Cohen, R. van Eldik, D. Meyerstein : J. Chem. Soc., Dalton Trans., 1998, 3663.

10) 川久保 進, 荻原清志, 岩附正明: 分析化学 (Bunseki Kagaku), 46, 381 (1997).

11) S. Kawakubo, H. Suzuki, M. Iwatsuki : Anal. Sci., 12, 767 (1996).

12) C. Reimann, P. de Caritat: "Chemical Elements in the Environment, Factsheets for the Geochemist and Environmental Scientist”, (1998), (Springer, Berlin).

13) R. M. Smith, A. E. Martell : “Critical Stability Constants", Vol. 6, Second Supplement, (1989), (Plenum Press, New York).

14) K. Hayakawa, Y. Hayashi : J. Nutr. Sci. Vitaminol., 23, 395 (1977).

15) P. Figura, B. McDuffie : Anal. Chem., 52, 1433 (1980).

16) S. Ohno, M. Tanaka, N. Teshima, T. Sakai : Anal. Sci., 20, 171 (2004).

17) H. Itabashi, H. Kawamoto, H. Akaiwa: Anal. Sci., 13, 411 (1997).

18) C. Angehrn-Bettinazzi : Int. J. Environ. Anal. Chem., 39, 81 (1990).

19) W. Kördel, M. Dassenakis, J. Lintelmann, S. Padberg: Pure Appl. Chem., 69, 1571 (1997).

20) G. C. Dwane, E. Tipping : Environ. Int., 24, 609 (1998).

21) S. Huang, Z. Wang, M. Ma: Chem. Spec. Bioavail., 15, 37 (2002). 


\title{
Speciation Analysis for Trace Copper in Natural and Tap Water by Catalytic Method
}

\author{
Susumu Kawakubo ${ }^{1}$, Hiromi Ogusu ${ }^{2}$ and Masaaki Iwatsuki ${ }^{1}$ \\ ${ }^{1}$ Interdisciplinary Graduate School of Medical and Engineering Science, University of Yamanashi, 4-3-11, \\ Takeda, Kofu-shi, Yamanashi 400-8511 \\ ${ }^{2}$ Department of Applied Chemistry and Biotechnology, Faculty of Engineering, University of Yamanashi, 4-3- \\ 11, Takeda, Kofu-shi, Yamanashi 400-8511
}

(Received 22 February 2011, Accepted 7 April 2011)

A catalytic spectrophotometric method for the determination of reactive copper in fresh water has been developed using the copper-catalyzed aerial oxidation of L-ascorbic acid to dehydroascorbic acid (DAA) and the formation of quinoxaline derivatives (QX) by the reaction of DAA with o-phenylenediamine at $\mathrm{pH} 6.9$ and $25{ }^{\circ} \mathrm{C}$. The absorbance of $\mathrm{QX}$ was measured at $340 \mathrm{~nm}$ for a reaction time of $5 \mathrm{~min}$. The calibration curve was linear up to $7 \mu \mathrm{g} \mathrm{\textrm {L } ^ { - 1 }}$ of copper. The detection limits were $0.1 \mu \mathrm{g} \mathrm{L}^{-1}$ for non-acidified samples and $0.5 \mu \mathrm{g} \mathrm{L}{ }^{-1}$ for acidified samples. Reactive copper species were characterized as $\mathrm{Cu}^{2+}$ and $\mathrm{Cu}^{\mathrm{II}} \mathrm{L}_{\mathrm{i}}$, where $i=1$ or 2 for a unidendate and $i=1$ for a bidentate ligand (L). The proposed method was useful to estimate reactive copper species, e.g., $40-65 \%$ as $\mathrm{Cu}^{2+}$ and $\mathrm{CuOH}^{+}$in tap water and 10 or $20 \%$ as copper complexed with humic substances like fulvic acid in river water. Unreactive copper species were also characterized.

Keywords : speciation; copper ; catalytic method ; natural and tap water. 